\title{
Macrothink
}

\section{The economic consequences of the incremental Internet disclosure: the case of French firms}

\author{
Moufida BEN SAADA: Associate Professor of Finance and Accounting \\ Affiliation: DEFI Laboratory, ESSEC, University of Tunis, Tunisia \\ Corresponding author: Moufida Ben Saada (110 cité balaoui Kairouan 3100 Tunisia) \\ Email : moufida_bensaada@yahoo.fr, Tel: 21622863490 \\ Hamdi KHALFAOUI: Associate Professor of Economics \\ Affiliation: PS2D Laboratory, FSEG, University of Tunis el Manar, Tunisia \\ Email: khalfaouihamdi@gmail.com, Tel : 21698951612
}

DOI: 10.5296/ijafr.v5i1.7613 URL: http://dx.doi.org/10.5296/ ijafr.v5i1.7613

\begin{abstract}
This study explores the economic consequences of incremental internet disclosure (IID) of 190 French companies pertaining to SBF 250 Index during 2012. we tested from a theoretical framework if the IID impacts the share's liquidity and the cost of equity as the traditional voluntary disclosure (TVD). The results, obtained from a cross-sectional regression, show that the IID is a benefit because it reduces the information asymmetry, which in turn increases the liquidity of securities' French firms. However, the IID has no impact on the cost of equity French firms.
\end{abstract}

Keywords: Iincremental internet disclosure, liquidity, information asymmetry, cost of equity capital. 


\section{MInstitute Macrothink $_{\text {Int }}^{\text {Intis }}$}

International Journal of Accounting and Financial Reporting

ISSN 2162-3082

2015, Vol. 5, No. 1

\section{Introduction}

The benefits of enhanced voluntary disclosure remain an ongoing debate among practitioners and researchers. According to economic theory and accounting thought, the commitment of firm to increase traditional voluntary disclosure(TVD), by annual reports, should reduce information asymmetry arising between potential sellers and buyers of firm' securities. In this context, a greater level of TVD lowers transaction costs and increase demand for firm's shares. Thus, the liquidity of shares increase and the cost of equity decrease (Copeland and Galai (1983), Kyle (1985))

Considering these benefits, firms attempt to use other developed types of disclosure such as Internet. Actually, most of the firms communicate their information on their websites (Ben Saâda et al 2010). By this channel, information can be accessed any time, everywhere at lower cost with dynamic presentation and multimedia (Wagenhofer (2003)).

Existing empirical research supports a positive association between TVD and liquidity of shares (Welker (1995), Leuz and Verrecchia (2000), Attig et al (2006)). However, empirical results studying the association between TVD and the cost of equity are mixed (Botosan 1997), Botosan et al (2002)). One explanation is that measurement of either TVD and the cost of equity isn't consensual.

Fewer are researches which examine empirically the benefits of Internet Disclosure (Froidevaux (2004), Lai et al (2010)). Besides, the economic consequence, there is no research that studies the economic consequence of the incremental internet disclosure (IID) provided by corporate website. More explicitly, there is no study that examines if the supplement of information available on corporate website affects securities' liquidity and the cost of equity of firm.

In this study, we explore the economic impact of IID of French firm. Specifically, we test if the IID, as for TVD, increases securities' liquidity and reduces the cost of equity. Using a sample of 190 French firms composing SBF 250 index that are listed on Euronext stock exchange during 2012, we find that IID increases shares' liquidity but has no effect on the cost of equity after controlling various firm characteristics.

The remainder of the paper is evolved as follows. We review prior research relating to the economic consequence of TVD and we develop our hypothesis in section 2 . We show sample selection procedure in section 3. We present our model and explain procedures used to measure IID, shares' liquidity and the cost of equity in section 4 . We present our empirical results in section 5 followed by conclusion in final section.

\section{Literature Review}

Several reasons push the firm to reduce information asymmetry between buyers and sellers of its shares on the market. The first reason is explained by the theory of market microstructure. In fact, thanks to an increased level of TVD, the cost of adverse selection, which is an important component of liquidity in a market order-driven, like the Euronext, is reduced. Therefore, the liquidity of securities increases. Empirically, several research studies argue that result. Welker (1995) studied the relationship between disclosure policy and the liquidity of the shares of 427 companies in 28 sectors observed over a period from 1983 to 
1990. The results of the simultaneous tests identify a significant negative relationship between the disclosure policy and the corresponding bid-ask spread.

Leuz C. and R. Verrecchia (2000) studied, from a sample of 102 German companies belonging to the DAX 100 Index during 1998, the economic consequences of increased TVD. In fact, these firms tried to improve their disclosure policy by adopting the Generally Accounting Accepted Principles in the US (US GAAP) instead of the International Accounting Standards (ISA). The result of the research shows that a greater commitment to publish the information according to "US GAAP" reduces the information asymmetry (assessed by the bid -ask spread) and accelerates the trading volume of the securities.

Study by S. Brown and S. Hillegeist (2005) have shown the existence of a negative relationship between the quality of TVD and the level of information asymmetry between investors. The sign of causality can be explained by the association between the quality of disclosure of private information and the frequency of arrival of such information. The second explanation relates to economic theory, mainly the cost of equity. The existence of a negative relationship between the TVD and the cost of capital was explained by two justifications: the first shows that greater disclosure of private information increases the liquidity of the shares, reducing thus the cost of capital through a reduction in transaction costs or through an increase in demand for the company's shares (H. Demsetz (1982), T. Copeland and Galai D. (1983), Y. Amihud and H. Mendelson (1986) and Diamond D. R. Verrecchia (1991)). The second argues that greater disclosure reduces the estimation risk when investors evaluate the parameters of an assets' returns (P. S. Handa and Linn (1993), J .Coles and U. Loewenstein (1995)).

Empirically, the results are mixed. C. Botosan (1997) shows a sample of 122 industrial US firms observed during 1990, an increase in the level of information provided via annual reports reduced the capital cost only for firms that are lowly followed by financial analysts. Botosan C. et al (2002) studied the relationship between the cost of capital and the level of voluntary financial reporting measured differently. The result of their studies is controversial. In fact, they show that voluntary communication via annual reports reduces the cost of capital. However, they find that the communication of quarterly reports increases the cost of capital, because this type of disclosure increases the volatility of securities prices. These studies have found no significant relationship between communication via the report of investors' relationship and the cost of capital.

A.-J. Mr. Richardson and Welker (2001) examine the relation between financial and social disclosure and the cost of capital for Canadian companies. They find that there is a significant and negative association between financial reporting and the cost of capital of firms that are lowly followed by financial analysts. However, there is a significant positive association between social communication and the cost of capital.

S. Kothari and J. Short (2003) examine the relationship between voluntary disclosure and the cost of capital estimated according to the three-factor model of Fama E. K. French (1997). The results show that only favorable disclosure reduces the cost of capital.

E. Froidevaux (2004) investigates the impact of the information disclosed in "Investor Relations" section of institutional websites on the cost of equity. From a sample of 141 US 
non-financial companies, he finds a significant and negative association between the level of Internet disclosure and the cost of equity.

Lai and al (2010) study the impact of Internet financial reporting (IFR) on stock prices of Taiwanese firms during 2002. They find that firms disclosing their information on web sites have more fluctuation of their stock prices and have abnormal stock returns than firms without IFR practice.

\section{Hypothesis development:}

As outlined in prior review, existent research confirms that increased level of TVD is negatively associated with the cost of equity and positively related to shares' liquidity. However, until now, there is no study that tests the effect of the supplement of information communicated by corporate websites on shares' liquidity and the cost of equity.

An increase in the quality and quantity of information provided two ways of reducing information asymmetry: the first shows that a greater disclosure of private information reduces information asymmetry, component of the bid-ask spread, and transaction costs. Consequently, informed investors lower the intensity of research activity that becomes costly. Uninformed investors raise the number of their order and take large position in a firm's stock. Thus, the liquidity of securities increases.

Thanks to attributes of the information provided by the corporate website, including punctuality, frequency of updates, interactivity and the ability to communicate as much information at a low cost, information asymmetry is reduced. Increased punctuality and the number of updates reduce the frequency with which some investors get private information. Therefore, the intensity of research activities conducted by informed investors becomes low, the number of orders issued by uninformed investors arises and the liquidity of securities increases. The discussion above supports our first hypothesis formulated as follow:

H1: Increased level of incremental internet disclosure rises the liquidity of French firms' securities.

Theoretical studies (Amihud and Mendelson (1986), D. Diamond and R. Verrecchia (1991)) show that the negative relationship between the level of voluntary disclosure and the cost of equity comes from transaction costs. Firms with wider bid-ask spread have a high cost of equity because investors require compensation for putting up additional transaction costs. Increased levelof disclosure decreases the cost of adverse selection component of the bid-ask spread, and reduces the cost of equity. Consequently, the amount of information that is revealed by large transactions is reduced, therefore allowing a decrease in prices associated with these transactions. In this situation, investors can take large positions in firms' stocks and increase the demand for firms' shares. Their corresponding prices rise and the cost of equity decreases. Arguments provided by these studies remain consistent for the IID. In fact, due to the specific attributes of the IID, namely timeliness and frequency of updates, the risk of information asymmetry decreases by lowering disclosure of private information. Therefore, the transaction costs become low and the demand for shares' firm rises reducing the cost of equity. We formulate our second hypothesis as follow:

H2: Increased level of incremental internet disclosure reduces the cost of equity of French firms. 


\section{Macrothink \\ International Journal of Accounting and Financial Reporting \\ ISSN 2162-3082 2015, Vol. 5, No. 1}

\section{Sample selection and description}

The initial sample consists of all French firms composing the SBF 250 index. we excluded from 250 firms 60 for which we haven't all the data on the bid-ask spread and the number of financial analysts. Ultimately, the final sample is consisted of 190 companies.

We review the corporate websites of every French firm included in SBF 250 to collect our data. We select the index SBF 250 because it regroups firms with different size small, medium and large. We defend this choice because the majority of studies have focused only on large firm composing the index SBF 120 or CAC40 (Attig and al (2008)).

The data on the bid-ask spread, the trading volume, and the volatility of returns are extracted from the "Data stream" system. The data relating to the number of followers analysts are from the database "Fact set" available at the Faculty of Economics and Management of Clermont-Ferrand. Data collection was based on a single year from 1er January to 31 December 2012. This choice reflects the temporal stability that is inherent to the financial communication policy of the companies.

\section{Empirical proxies and models}

\subsection{Shares' liquidity}

To measure shares' liquidity, we use the bid-ask spread. This proxy reflects explicitly the information asymmetry. The bid-ask spread that we use is the average relative spread computed as absolute spread divided by the average of bid and ask from January to December 2012.

average relative spread $=\frac{\mid \text { bid }- \text { ask. } \mid}{\frac{\text { bid }+ \text { ask. }}{2}}$

We got monthly average bid and ask from Data stream system which gives data market of the Euro next stock exchange. The monthly average is measured as the mean relative spread calculated daily per firms.

\subsection{Cost of equity capital}

Many studies were used to estimate the cost of equity ${ }^{1}$. In this study, we use the accounting approach called the classical model of dividend growth (Botosan (1997), Botosan and al (2002)). In this model, the cost of equity capital of a firm (r) is a function of expected dividend $\left(D_{T+1}\right)$ divided by a market price of a firm s'stock $\left(\mathrm{P}^{t}\right)$ and a constant rate of dividend's growth (g). the model is written in the following form:(r) $=\frac{D_{t+1}}{P_{t}}+g$, where $D_{t+1}$ is the dividend paid in year $t+1$, the year 2008 given in the annual report of the firm, $P_{t}$ is the average daily market price of a firm's stock during the year 2012 and calculated from data stram, and (g) is the rate of growth of dividend calculated during two previous years 2011 and 2012.

\footnotetext{
${ }^{1}$ For a detailed list of models used to approximate cost of capital, see Botosan et al(2002).
} 


\section{MlMacrothink}

International Journal of Accounting and Financial Reporting

ISSN 2162-3082

2015, Vol. 5, No. 1

\subsection{Incremental internet disclosure (IID)}

Few studies have used disclosure index to measure the level of communication on corporate website. In this study, we construct an internet disclosure index based on the work of Marston and polei (2004) and Xaio and al (2004). We follow the same procedure used by Botosan to calculate the items of disclosure index. The items composing the internet disclosure index is given in table 1.The internet disclosure index is composed of 69 items. It includes 42 items related to content and 27 items related to the form of presentation. Table 1 provides a detailed list of types of information as well as their weight in scores of Internet Disclosure (ID).

Table 1. Description of the components of the scores of the ID

\begin{tabular}{|l|l|}
\hline Types of information & Number of items \\
\hline * Strategic information & 13 \\
\hline *Other financial and non-financial information & 15 \\
\hline \&Information on Governance & 14 \\
\hline I. Total Website Content (I) & $\mathbf{4 2}$ \\
\hline II.Total website presentation (II) & $\mathbf{2 7}$ \\
\hline \&Information technology configuration & 14 \\
\hline \&Information about convenience and use of the website & 13 \\
\hline III.Total Score (I+II) & $\mathbf{6 9}$ \\
\hline
\end{tabular}

The calculation of the internet disclosure index is as follows: We place Note 1 for each item posted on the company's website and a score of 0 other way (Botosan (1997)). Companies with an inaccessible site which is protected by a pass word or having a commercial website have respectively total zero content score. The calculated index takes the following form: $\mathrm{ID}_{j}$

$=\sum_{i=1}^{n} x_{i j}$

, where: $\mathrm{ID}_{\mathrm{j}}$ is the index that measures the internet disclosure of a firm $\mathrm{j}, \mathrm{n}$ is the theoretical score and $x_{i j}=1$ if item $\mathrm{i}$ is published by the company $\mathrm{j}$. Traditional disclosure (TD), which represents the communication of the information by annual report, is measured

by Botosan's index (1997). It is computed as follow: $\mathrm{TD}_{\mathrm{j}}=\sum_{i=1}^{n} y_{i j}$, where $\mathrm{TD}_{\mathrm{j}}$ is the index that measures the traditional disclosure of a firm $\mathrm{j}, \mathrm{n}$ is the theoretical score and $y_{i j}=1$ if item $i$ is published on annual report of a company $j$.

The score of incremental internet disclosure (IID) is the additional information provided by the websites of the French companies. It is calculated as follows:

$\Delta(\mathrm{IID})=\mathrm{ID}_{\mathrm{j}}-\mathrm{TD}_{\mathrm{j}}$ With $\Delta(\mathrm{IID})$ is the difference between the score of financial communication through the Internet and the score of traditional financial communications, $\mathrm{ID}_{\mathrm{j}}$ is the Internet disclosure index, $\mathrm{TD}_{\mathrm{j}}$ is the traditional communication by annual report. The list of items 


\section{Macrothink \\ International Journal of Accounting and Financial Reporting \\ ISSN 2162-3082 \\ 2015, Vol. 5, No. 1}

forming the index of ID and the index of TD is provided by the following tables:

Table 2. List of items composing the Internet disclosure index

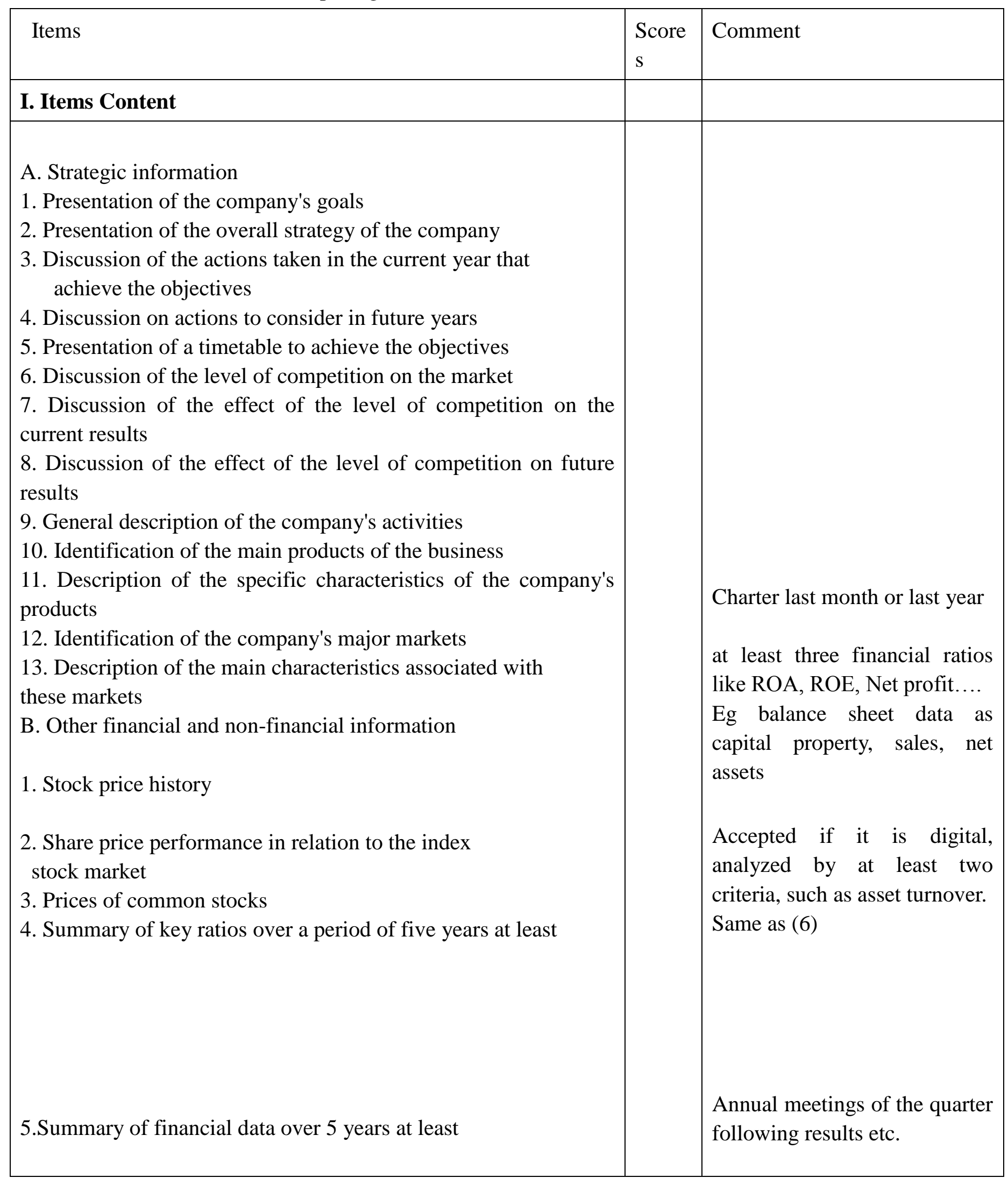


6. Communication segmented by product line

7. Communication segmented by region

8. Shareholding Structure

9.Financial Calendar

10. Intermediate state

11. Environmental Report or special page

12. Report on the employees or the social security or health

13. Commercial Sponsorship

14. Involvement in a non-profit community

\section{Current Press Statement}

C. Governance information

1. Notice of meetings and agenda of the annual meetings shareholders

2. Voting results of the Annual General Meeting (AGM)

3. Discourse of the President of the executive board

4. Business Articles

5. Ethical Code

6. $\mathrm{CV}$ of the Management Board

7. Evaluations of analysts
No package if it is a general remark on the environment, special strategies must be specified

Ex sport or event

Support cultural project, local organization, specific foundations etc.

Last recent statement of at least 1 month and is updated through internal or external links

Manuscript, video or sound file

Purchasing, holding, sale, and the name of the institutions of recent analyzes, at least

3 months and at least 2 different opinions.

Quantitative estimates

Individualized and subdivided, fixed or varied according to the performance of the firm

Same as (9)

Accepted if they are on a separate page of the annual report

Same as (11)

Ex mandates of the Supervisory Board 
8. Analyst Estimates

9. Remuneration of the Management Board

10. Remuneration of the Supervisory Board

11. Information on previous positions held by the leader

12. Information on stock option programs

13. Additional activities of members of the Board management

14. Press Documentation and analyst conference

\section{Presentation items}

A. Technology configuration

1. Download time of website $<10$ seconds

2. Alternative text available

3. Internal link in the Annual Report

4. Financial data in Excel format

5. Annual Report in PDF format

6. Annual report in html format

7. Graphic images

8. Flashes

9. Sound files
Video, audio file or PDF file

Ex balance sheet with notes

On the main page or on section investor relations

Mention technical support

more advanced than F3, the menu opens when the mouse pointer moves on the title

eg to request the annual report on paper

to give news to investors

eg for the balance sheet

1 click events is coded 1 , more than one is coded 0

Same as (11) 


\section{Macrothink}

10. E-mail Video file for investor relations

11. Phone number for Investor Relations

12. Postal address to Investor Relations

13. English version of the homepage

14. Frequently Asked Questions

B. Suitability and use of the website

1. Support Site

2. Table of content, site map

3. Menu "close"

4. Menu "open"

5. Internal Search engine

6. "Previous" Button "Next" to navigate sequentially

7. Direct Email Link to Investor Relations

8. Online Information Service for investor relations

9. Mailing list

10. Documents ready to be printed

11. Number of clicks to have information for investors

12. Number of clicks for press statements or new

13. Existence of audited annual report 


\section{Macrothink \\ International Journal of Accounting and Financial Reporting \\ ISSN 2162-3082 \\ 2015, Vol. 5, No. 1}

Table 3. List of items composing the TD index constructed by Botosan 1997

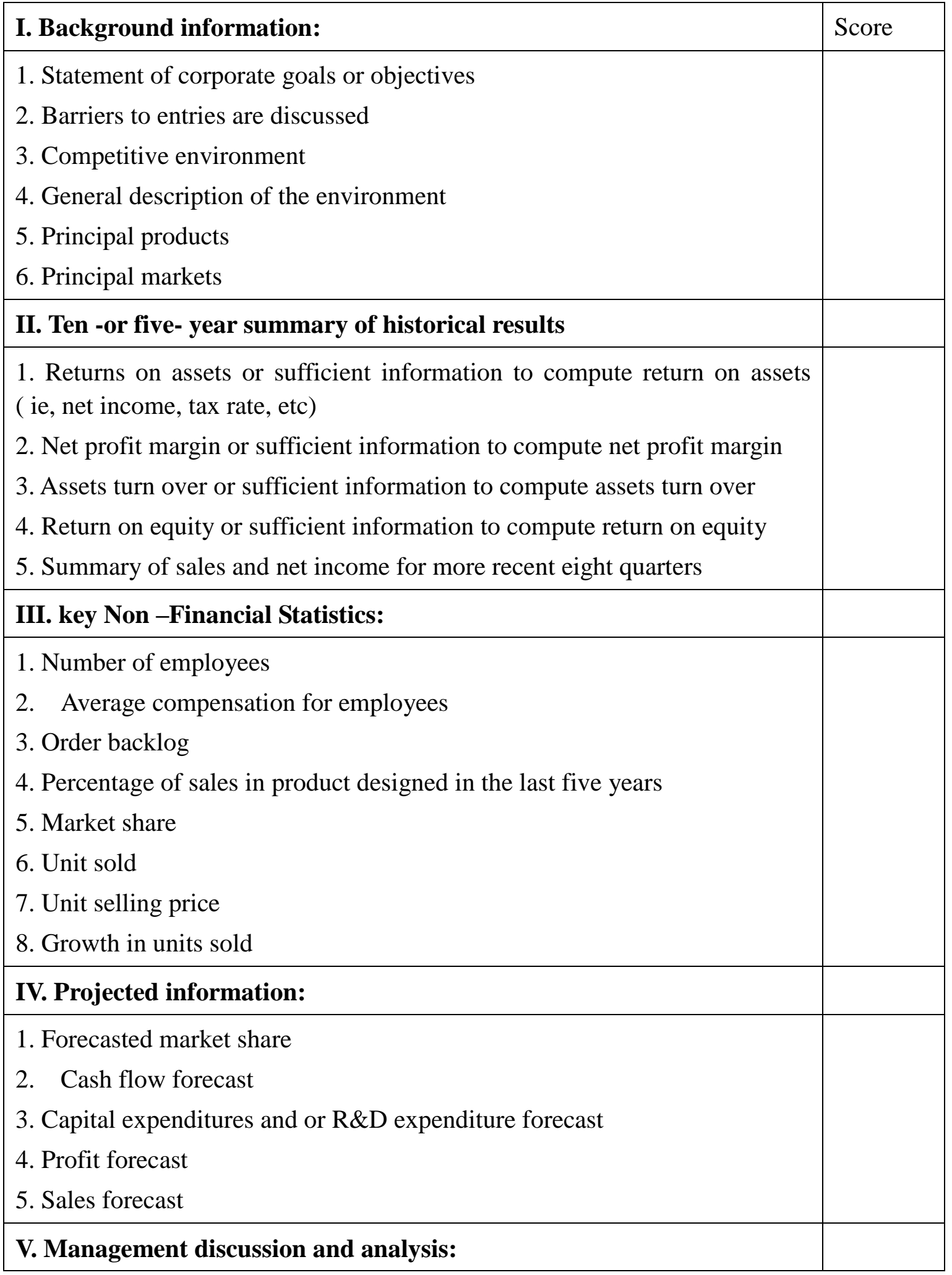


1. Change in sales

2. Change in operating income

3. Change in cost of goods sold

5. Change in gross profit

6. Change in selling and administrative expenses

7. Change in interest expense or interest income

8. Change in inventory

9. Change in accounts receivable

10. Change in capital expenditure or R\&D

11. Change in market Share

4.4. Control variables

\section{4 measurements of control variables}

4.4.1 Volatility of returns: We measured volatility by the standard deviation of daily dividend adjusted returns of the firm between $1 / 1 / 2012$ to $31 / 12 / 2012$.

4.4.2Trading volume: We measured the trading volume by the median daily turnover ratio, ie, values of all securities traded at Euronext exchange divided by the market capitalization, between 1/1/2012 to 31/12/2012. All data of price and volume are obtained from DataStream system.

4.4.3 Behavior of financial analysts: We selected the number of analysts following a company as a measure of the behavior of financial analysts.

4.4.4 Leverage: we measured leverage by total debt divided by the total Assets of firm $j$ at time $\mathrm{t}$.

4.4.5 Size: We measured size by the logarithmic value of the total assets of the company.

\subsection{Regression models}

\subsubsection{Reliability Assessment of IID}

To assess the reliability of the components of the total score of the IID, we used the Cronbach alpha coefficient LJ (1951). The Cronbach alpha coefficient obtained is equal to 0.8846 . Therefore, items constituting the financial communication score are consistent.

\subsubsection{Regression model and estimation method}

We use two regression models. In The first, we test if IID affects shares' liquidity. In the second model, we test if IID impacts the cost of equity. In the two models, we include the control variables noted above. Regression models are written as follows:

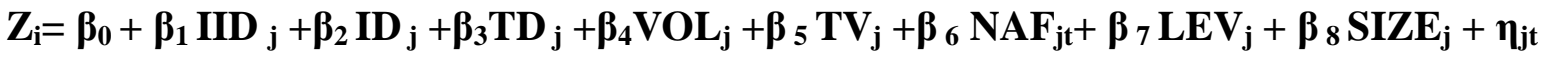

Legend 1: For a firm $j$, we have: $Z$ :The average relative spread in the Equation 1.In Equation $2, \mathrm{Z}$ is the cost of equity. $\operatorname{IID}_{\mathrm{j}}$ is the incremental internet disclosure, $\mathrm{ID}_{\mathrm{j}}$ is the internet disclosure, $\mathrm{TD}_{\mathrm{j}}$ ist he traditional disclosure, $\mathrm{Vol}_{\mathrm{j}}$ is the standard deviation of daily dividend adjusted returns between $1 / 1 / 2012$ to $31 / 12 / 2012, \mathrm{TV}_{\mathrm{J}}$ is the median daily turnover ratio, ie, 


\section{Ml Macrothink}

International Journal of Accounting and Financial Reporting

ISSN 2162-3082

values of all securities traded at Euro next exchange divided by the market capitalization, between $1 / 1 / 2012$ to $31 / 12 / 2012$. $\mathrm{NAF}_{\mathrm{j}}$ : Number of financial analysts following a firm, Leverage $\mathrm{j}_{\mathrm{j}}$ is measured by total debt divided by total assets, Size $\mathrm{j}_{\mathrm{j}}$ is the logarithm of the total asset, $\beta$ is a constant and $\eta_{\mathrm{jt}}$ is a residual error term.

\section{Results}

\subsection{Descriptive analysis of variables}

Table 4 shows the characteristics as mean and standard deviation of the dependent variables and independent variables as well.

Table 4. Descriptive statistics of variables

\begin{tabular}{lll}
\hline Variables & Mean & $\begin{array}{l}\text { Standard } \\
\text { deviation }\end{array}$ \\
\hline Bid-askspread & .0058 & .0086 \\
R & .0529 & .0800 \\
IID & 7.455 & 11.949 \\
ID & 35.295 & 13.069 \\
TD & 28.135 & 11.798 \\
TV & .005 & .014 \\
VOL & .01681 & .00629 \\
NAF & 9 & 6 \\
LEV & .7653 & 1.0263 \\
SIZE & 11.2216 & 2.5269 \\
\hline
\end{tabular}

Table 4 shows that the sample of French companies forming the SBF250 index have on average a very narrow bid- ask spread (0.005). We deduce that French firms have on average high liquidity of their securities. The cost of equity is low on average. Level of internet disclosure and traditional communication are quite high on average. The extend of incremental internet communication is low on average.

From Table 4, we find that, on average, French firms are followed enough by financial analysts, and have high volatility of returns and high trading volume as well. French firms are on average levered and large.

We conduct the test nonparametric of spearman s' correlation. We find that the bid ask spread is significantly and negatively correlated with IID, ID and TD. However, it seems that the IID is not correlated with the cost of equity although it confirms the predicted sign (negative).

\subsection{Regression results}

Table 5 presents regression results according to Double Ordinary Least Square method (DOLS). This method is used because the incremental communication score (IID) is correlated with ID. Therefore, we cannot include in the same model the IID and ID when we use the method of ordinary least square (OLS). The DOLS method is used to correct this problem.

Table 5. Results of tests of hypotheses of equations (1) and (2) by the method of 


\section{Macrothink \\ International Journal of Accounting and Financial Reporting

double-ordinary least square "DOLS Robust"

\begin{tabular}{lll}
\hline & Equation (1) & Equation (2) \\
\hline $\mathrm{R}$ & & \\
Bid-askspread & & $(-1.77)^{*}$ \\
$\mathrm{IID}$ & $(-1.86)^{*}$ & $(-0.77)$ \\
$\mathrm{TD}$ & $(-0.258)^{* *}$ & $(-0.33)$ \\
$\mathrm{TV}$ & $(11.11)^{* * *}$ & $(0.29)$ \\
VOL & $(-9.98)^{* * *}$ & $(-1.90)^{* *}$ \\
NAF & $(-3.58)^{* * *}$ & $(-2.41)^{* *}$ \\
LEV & $(-0.85)$ & $(-0.52)$ \\
SIZE & $(-1.26)$ & $(1.000)$ \\
\hline Observations & 190 & 190 \\
R-squared adj & 0.857 & 0.091 \\
\hline *** correlation significant at 0.01, & c* correlation significant at 0.05, \\
* correlation significant at 0.1 &
\end{tabular}

Legend 2: For a firm $\mathrm{j}$, we have the average relative bid-ask spread in the Equation 1 and in Equation2, the cost of equity ( $r$ ) as dependant variables. IID $_{\mathrm{j}}$ is the incremental intern disclosure, $\mathrm{ID}_{\mathrm{j}}$ is the internet disclosure, $\mathrm{TD}_{\mathrm{j}}$ is the traditional disclosure, $\mathrm{Vol}_{\mathrm{j}}$ is the standard deviation of daily dividend adjusted returns between 1/1/2012 to $31 / 12 / 2012, \mathrm{TV}_{\mathrm{J}}$ is the median daily turnover ratio, ie, values of all securities traded at Euronext exchange divided by the market capitalization, between $1 / 1 / 2012$ to $31 / 12 / 2012 . \mathrm{NAF}_{\mathrm{j}}$ : is the number of followers financial analysts, Leverage is measured by total debt divided by total assets, $\mathrm{SIZE}_{\mathrm{j}}$ : is the logarithm of the total asset, $\beta$ is constant $a n d \eta_{\mathrm{jt}}$ is a residual error term.

From this table, we see that an increased level of IID is negatively and significantly (at level of $10 \%$ ) associated with liquidity. This increase narrows the spectrum of information asymmetry between informed investors and those uninformed. Therefore, shares 'liquidity increases. This first result corroborates those of the following work (M. Welker (1995), C. Leuz and R.Verrecchia (2001), S. Brown et al (2005)). From Table 5, we denote that traditional disclosure (disseminated by annual reports) is associated negatively and significantly (at a level of 5\%) with shares' liquidity. This result confirms previous finding of the following work (M. Welker (1995), A. and K. Hutton Palepu (1999), C. Leuz and R.Verrecchia (2000), N. Attig et al (2006)).

Regarding the control variables, we see from Table 5 that the coverage of financial analysts and trading volume are negatively and significantly (to a level of 1\%) associated with the relative bid-ask spread. Financial analysts are considered as information providers who communicate to their customers the additional information that is not disseminated by the company. Consequently, by their communication, they reduce the information asymmetry and increase shares' liquidity. Moreover, a high trading volume of securities exchanged increases the immediacy and the depth, which are two very important dimensions of liquidity. As for volatility, we notice that it is positively and very significantly associated with the relative bid-ask spread. Thus, high volatility reflects a significant risk of securities. In such a situation, 


\section{MInstitute Macrothink $^{m}$}

International Journal of Accounting and Financial Reporting ISSN 2162-3082 2015, Vol. 5, No. 1

investors are reducing their orders. Therefore, the non-execution of the latter leads to a reduction in liquidity. Unlike market variables, variables related to leverage and size are not associated significantly with the relative bid-ask spread.

Regarding the second equation, we show that IID is not significantly related to the cost of equity while it confirms the expected sign (negative). We conclude that the additional information provided by the Internet has no effect on the cost of equity. This result can be explained by two difficulties: the first relates to the empirical measurement of the disclosure variable. Indeed, there is no a single list for the computation of the communication index. Therefore, every study uses its list to calculate score of voluntary disclosure. Hence, the index used in this article to calculate the IID is the work of the authors. The second relates to the measurement of the cost of equity. There are studies that have estimated the cost of equity indirectly through its component information asymmetry. This component is measured differently by the bid-ask spread, the trading volume, the dispersion of analysts' forecasts or price volatility (Mr. Welker (1995), A. and K. Hutton Palepu (1999), C. Leuz and R. Verrecchia (2000)). These studies have validated the finding that a high voluntary communication reduces information asymmetry. Other studies have estimated the cost of equity by different models that in turn raise the problem of quantitative estimation of the cost of equity. Some studies measured the cost of equity using an ex-post estimate as the CAPM. They have not empirically validated the association between voluntary disclosure and the cost of equity (K.French E. Fama (1997). Other studies have measured the cost of equity using an ex-ante estimate as models dividend growth of cash flows (Botosan C. (1997), C. Botosan and M.Plumlee (2000), E. Froidevaux (2004)). These studies have found mixed results as presented above in the literature review. Concerning traditional disclosure, we note that it has no significant impact on the cost of equity. We conclude that the additional information provided by the Internet and the voluntary communication have no influence on the cost of equity.

Table 5 shows that the cost of equity is significantly (at level of 10\%) and negatively associated with the relative bid-ask spread. This cost is also significantly related (at level of $5 \%$ ) and negatively to price volatility and to the number of financial analysts following French companies. We conclude that high shares' liquidity, low volatility and significant following of financial analysts reduce the information asymmetry in the capital market, enabling French companies to have a low cost of equity.

\section{Conclusion}

In This study, we explore the economic impact of the incremental internet disclosure (IID). Specifically, we test the impact of IID on shares' liquidity of French companies and on their cost of equity. From the theory of the microstructure, we assumed first, that an increase in the level of IID has a positive effect on the securities" liquidity. In fact, incremental financial communications via the Internet reduces information asymmetry between informed investors and those uninformed and therefore allows an increase in liquidity. Secondly, we have assumed that increasing the level of IID reduces the information asymmetry, which in turn decreases the cost of equity of French companies.

Our results confirm the negative impact of incremental financial communication on shares' 


\section{Mll Macrothink}

International Journal of Accounting and Financial Reporting ISSN 2162-3082 2015, Vol. 5, No. 1

liquidity. More specifically, we found that increasing the level of IID, lowers information asymmetry by reducing the bid ask spread. Consequently, it allows an increase in liquidity.

We don't confirm in this study that the IID is significantly and negatively associated with the cost of equity of French firms. In fact, the additional information provided by corporate websites of French firms does not reduce their cost of equity. This conclusion is not surprising since the results from the majority of studies have not definitively approved the significant negative impact of voluntary financial reporting on the cost of equity. These results are explained by the variety of estimates used to measure both the score of voluntary financial disclosure and the cost of equity. Corroborating the results of previous studies, we find that the liquidity of securities and the cost of equity of French firms are dependent on a significant coverage of financial analysts and a low volatility of returns.

\section{References}

Alfred, W. (2003).Economic Consequence of Internet Financial Reporting. Schmalenbach Business review.vol 55, p 262-279.

Amihud, Y., \& Mendelson, H. (1986a), "Asset Pricing and Ask-Bid Spread", Journal of Financial Economics, vol 42, p 223-249.

Amihud, Y., \& Mendelson, H. (1986b), "Liquidity and Stock Return", Financial Analysts Journal, vol 42, pp. 43-48.

Attig, N.Wai, M.F.Yoser, G. Larry, HP. L. (2006).Effects of large shareholding on information asymmetry and stock liquidity.Journal of Banking and Finance.vol 30, p 1-18.

Ben Saada, M. Khalfaoui, H. Vedrine, J.P. Mamoghli, C. (2010). Impact de la communication financière et incrémentale par Internet sur la liquidité des titres des entreprises francaises. La Revue des Sciences de Gestion, Direction et Gestion. 242,p 39-48 DOI: $10.1051 / \mathrm{larsg} / 2010026$

Botosan, C. (1997).Disclosure level and the cost of equity capital. The Accounting Review.vol 72 , p. $323-349$.

Botosan, C., \& Plumlee, M. (2002). Re examination of disclosure level and the expected cost of equity capital. Journal of Accounting Research, vol 40, pp $21-40$.

Brown, S. Stephen A.H. (2005). Disclosure quality and information asymmetry.Working paper, 40 pp.

Coles, J. Loewenstein, U. Suay, J. (1995).On Equilibrium pricing under parameters uncertainity. Journal of Financial and Quantitative Analysis. September, p 347 - 364.

Coles, J. Loewenstein, U.Suay, J. (1995). On Equilibrium Pricing Under Parameter Uncertainty.Journal of Financial and Quantitative Analysis. September, p. 347-364

Copeland, T. Galai, D. (1983).Information effects on the bid- ask spread, The Journal of Finance.p 1457- 1469.

Cronbach, L.J. (1951). Coefficient alpha and the internal structure of tests. Psychometrika.vol $16, \mathrm{p} 297-334$.

Demstez, H. (1982). The cost of transacting.Quarterly Journal of Economics.February, p 33 - 


\section{Ml Macrothink}

International Journal of Accounting and Financial Reporting ISSN 2162-3082 2015, Vol. 5, No. 1

53.

Diamond, D. Robert, V. (1991).Disclosure, liquidity and the cost of capital. The Journal of Finance.vol 66, p 1325 - 1355.

Easley, D. Kiefer, N.M. O'Hara, M. (1997).The information content of the trading process. Journal of Impirical Finance.vol 4, p. 159-186

Fama, E.F. Kenneth, F.R. (1997).Industry cost of equity. Journal of Financial Economics.vol 43, p 153-193

Handa, P. Linn, S. (1993). Arbitrage Pricing With Estimation Risk.Journal of Financial Economics, March, p. 52-100.

Healy, P. Hutton, A. Krishna, G.P. (1999).Stock performance and intermediation changes surrounding sustained increases in disclosure. Contemporary Accounting Research.vol 16, p 485-520.

Healy, P.M. Krishna, G.P.(2001). Information asymmetry, corporate disclosure and the capital markets, a review of the empirical disclosure literature.Journal of Accounting and Economics.vol 31, p 441- 456.

Kothari, S.P. Short, J. (2003).The effect of disclosures by management, analysts, and financial press on the equity cost of capital,Working paper.Sloan School of Management Massachusetts Institute of Technology.

Kyle, A. (1985). Continuous Auctions and Insider Trading. Econometrica, vol 53, p1315-1335.

Leuz, C. Verrecchia, R. (2000). The economic consequences of increased disclosure. Journal of Accounting Research.vol 3, 63pp.

Marston, C.L., \& Polei, A. (2004). Financial reporting on the Internet by german companies. International Journal of Accounting Information Systems, vol 5, p 285 - 311.

Richardson, A.J. Michael, W. (2001). Financial disclosures, social disclosures and the cost of equity capital.Accounting, Organizations and Society. V26 N7/8: 597-616.

Syou-Ching, L. Cecilia, L. Hung-chih, L. Frederick, H. Wu (2010).An empirical study of the impact of IFR on stock prices.The International Journal of Digital Accounting Research.vol 10, p 1-26.

Verrecchia, R. (2001).Essays on disclosure.Journal of Accounting and Economics.vol 32, p. 97-180.

Wagenhofer, A. (2003). Economic consequences of Internet financial reporting. Schmalenbach Business Review, vol 55, p 262- 279.

Welker, M.A. (1995).Disclosure policy, information asymetry and liquidity in equity markets.Contempory Accounting Research.vol 11, p 801-828.

Xiao, J.Z., Chow, C.W., Hang, H. (2004). The determinants and characteristics of voluntary Internet-based disclosures by listed Chinese companies, Journal of Accounting And Public Policy, vol 23, p $191-225$.

Yakov, A. Mendelson, H. (1986a). Asset Pricing and Ask-Bid Spread.Journal of Financial Economics.vol 42, p 223-249. 